\title{
Implementation of Decent Work and Perception of Quality of Work-Life for Workers in PT AG
}

\author{
Atika Amalia $^{1}$, Riani Rachmawati ${ }^{2}$ \\ \{amalia.atika78@gmail.com ${ }^{1}$, riani.rachmawati@gmail.com ${ }^{2}$ \} \\ University of Indonesia
}

\begin{abstract}
This paper discusses the implementation of decent work and the perception of work-life quality owned by workers in Regionally-Owned Enterprise in transportation services sector, namely PT AG. To describe the phenomenon of decent work, the authors use 10 decent work indicators conveyed by ILO (2013), while in providing an overview of the quality of work-life, the authors use dimensions from Bustillo (2009) and Moos (1974, 1981, 1994). Data are obtained by interviews with nine workers, where there is a group of field workers and head office workers, and informants were chosen using purposive sampling. The findings of this research indicate that PT AG seeks to create decent working conditions through adequate earnings and productive work, compliance with regulations related to work that should be abolished, stability and job security, social security, as well as providing a mechanism for conducting social dialogue at work. However, PT AG's management needs to pay more attention to decent working hour indicator, combining work, family and personal life, equal opportunities and treatment in employment, and safe work environment. Findings related to the quality of work-life are also illustrated by the field workers, specifically related to work quality issues. These findings can be an input for stakeholders and management related to the implementation of decent work that is substantial for the lives of workers and business continuity of the company.
\end{abstract}

Keywords: Decent Work, Quality of Work-Life, Regionally-Owned Enterprise.

\section{Introduction}

Working is one of the mechanisms to fulfill basic human needs; both material and non-material, such as needs of security, socializing, and selfactualization. However, having merely a job is not enough to be said that humans have met their standard of living, but working in decent situations and conditions is the answer (Burchell, Sehnbruch, Piasna, \& Agloni, 2013). Regarding to the importance of fulfilling the decent aspect, the International Labor Organization (ILO) then aggressively campaigned for decent work, starting with the initiative carried out by Juan Somavia in 1999. 
The terminology of decent work according to the ILO focuses on issues related to job content, work environment, employee's perceptions of their work, also regarding to employment issues such as labor rights, gender inequality, and work-life balance (Burchell et al., 2013). According to ILO (2012) conditions that can be categorized as 'decent' is also including the availability of opportunities to obtain productive work, a work environment that upholds labor rights, provides freedom, and meet the needs of security and protection (Tadjoeddin, 2014).

As the main focus of this paper, the concept of decent work is also related to the concept of work-life quality. The quality of work-life is one of the issues raised in the concept of decent work. With a smaller scope, the quality of worklife is talking about the internal scope of the organization: Related to job satisfaction, work improvement, work involvement and job autonomy, while the concept of decent work addresses both micro and macro scopes, such as unemployment, poverty, and related to the economic and social context in a region (Adhikari, Hirasawa, Takakubo, \& Lal Pandey, 2011).

In regard to the concept of decent work, this paper focuses on the context of labor in Indonesia. The main question is, how is the implementation of decent work in Indonesia's labor context? The phenomenon of the decent work in Indonesia was explained in the Decent Work Indicators in Indonesia (2018) reported by BPS-Statistics Indonesia. Based on data from the National Labor Force Survey (Sakernas), BPS concludes that Indonesia is still struggling with the efforts to fulfill decent work for the civil society, in accordance with the four major strategic objectives set by ILO: rights at work, employment and income opportunities, social protection, and social dialogue.

The research in this paper focuses on the Regionally-Owned Enterprise in transportation services sector, namely PT AG. The company was chosen as the object of the research because of its unique challenges. On January 2020, the local online media reported that a woman who work as a bus service officer was found passed away in the bus stop. According to Koran Tempo ${ }^{1}$, the worker was experiencing health problem and requested permission from her supervisor to rest at home, but the permission was rejected. Another news has spread when the workers held a demonstration at the PT AG Head Office and in front of the City Hall. The news that was published on Kompas ${ }^{2}$ said that hundreds of workers demanded certainty about their employment status because they had previously been promised to be appointed as contract employees after the internship period ended. However, the "promises" they had hoped would not be realized because the working period was extended by the management for an

${ }^{1}$ Published on January 28, 2020

${ }^{2}$ Published on December 30, 2019 
undetermined time. Although the management of PT AG has provided clarification related to the news, but the news spread has made the issue of employment and workers' welfare at PT AG then questioned. In regard to its ownership status, all the issues carried out by PT AG are always interesting to be captured by various parties, especially the mass media. On the other hand, PT AG employs field workers such as driver, bus service officer, and patrol officers who have high risk jobs. For drivers, bus service officers, and patrol officers, the risk of having a traffic accident can lurk at any time. In addition, specifically for patrol officers who are tasked with maintaining bus lane sterilization and smooth traffic on the highway, the risk of exposure to air pollution and erratic weather is also experienced by them. Other conditions experienced by bus service officers as front liners who are responsible for maintaining security on the bus. As officers who interact with customers, sometimes they experience unpleasant treatments such as complaints from customers so it could trigger the potential to negative emotions. The types of work have the potential to affect the physical and psychological health conditions of workers, as well as the potential for traffic accidents.

According the background of this research, the main questions are:

1. How is the implementation of decent work for workers who have high risk jobs at PT AG?

2. How is the quality of work-life interpreted by workers who have high risk jobs at PT AG?

To describe the phenomenon of decent work, the author uses 10 decent work indicators conveyed by ILO (2013), while in providing an overview of the quality of work-life, the author uses dimensions from Bustillo (2009) and Moos $(1974,1981,1994)$.

\section{Literature Review}

The concept of decent work was proposed by the International Labor Organization (ILO) in 1999. The concept was driven by the gap between the real conditions faced by workers and the conditions expected to occur in the workplace, as an improvement of the quality of life (ILO, 2001). At first, the concept of decent work was regarded as an opportunity for women and men to get decent and productive work in an environment that upholds freedom, equality, security, and human dignity (Adhikari et al., 2011). Decent work is then interpreted as work that provide adequate opportunities and remuneration 
for work, social security, incorporates fundamental rights of workers relate to freedom of association, non-discrimination in work, and the absence of forced labour and child labour in abusive conditions (ILO, 2002). Decent work can also be interpreted as a good opportunity in the work environment related to personal development and social integration, as well as the freedom to express aspirations, organize, and participate in decisions that affect the lives of workers (ILO, 2008). Over time, the concept of decent work has expanded its meaning. According to ILO (2020), decent work also involves the opportunities for work that is productive and delivers a fair income, security in the workplace and social protection for families, better prospects for personal development and social integration, freedom for people to express their concerns, organize and participate in the decisions that affect their lives and equality of opportunity and treatment for all women and men.

BPS- Statistic Indonesia also shares the concept of decent work. According to Decent Work Indicators in Indonesia (2018), decent work is regarded as work that ensures every worker works productively and fulfills human rights as a human being. These rights including personal growth, adequate earnings, stability and security of work, social protection for workers and their families, as well as the right to express opinions, organize, and be involved in making decisions that affect workers' lives. Thus, it can be concluded that the main point in the issue of decent work is that every human being has the right to get decent work and uphold humanitarian values in accordance with the ILO's four principal values: freedom, equity, security, and human dignity.

In the Decent Work Agenda (ILO, 2013), ILO proposed ten indicators of decent work. These elements are related to (1) employment opportunities, (2) adequate earnings and productive work, (3) decent working time, (4) combining work, family, and personal life, (5) work that should be abolished, (6) stability and security at work, (7) equal opportunity and treatment in employment, (8) safe work environment, (9) social security, and (10) social dialogue, workers' and employers' representation. These elements set out from the ILO's principle values.

The concept of decent work is also related to the concept of quality of worklife. The concept was interpreted by Cascio (2006) as "A set of objective organizational conditions and practices designed to foster quality relationships within the organizations; employees' perceptions of the degree to which the organization environment meets the full range of human needs". Both decent work and quality of work life are talking about adequate earnings, security at work, as well as rights to join the labor union and expressing themselves in the workplace. However, the concept of decent work addresses broader issues compared to the quality of work-life. The definition of decent work covers both 
formal and informal sectors, while the quality of work-life focuses on the quality of service in the internal sector (Adhikari et al., 2011).

In the era of scientific management, the term of quality of work-life is based on extrinsic traits of job, such as salaries, safety and hygiene, and other tangible benefits of the workplace (Adhikari et al., 2011). The term then experienced an expansion in scope. According to Adhikari et al (2011), the quality of work-life in the human relations approach is also related to the intangible factors such as job autonomy, challenges at work, and task contents, which also have a significant effect on productivity at the workplace.

The quality of work-life can be seen from two perspectives; from the perspective of the organization and the perspective of workers. In terms of workers, the idea of the quality of work-life is closely related to the terms of "internal service quality" and has a positive influence on employee satisfaction (Adhikari et al., 2011). It also can be said that quality of work-life is a condition where the employees guarantee job security, adequate earning and benefit, and meaningful job. Furthermore, the quality of work-life is also interpreted by the creation of a safe and healthy work environment, as well as providing flexibility for workers to express themselves and speak their aspirations. Thus, Cascio (2006) argues that the quality of work-life from the perspective of workers is related to physical and mental health felt by workers. From the organizational perspective, fulfilling the quality of work-life includes an understanding that workers should be seen as valuable resources because they can contribute to the organization's performance, so they must be treated well and with appreciation (Straw and Hecksher, 1984 in Anbarasan and Nikhil, 2010). Conditions that will disrupt organizational productivity, such as loss of workforce and high turnover, can be reduced if the organization is committed to creating a quality of worklife.

According to Moos $(1974,1981,1994)$, to have better understand about the quality of work-life, there are three dimensions that can be seen: (1) basic social dimensions, (2) personal growth dimension, and (3) system maintenance and change dimensions (Anbarasan \& Nikhil, 2010). Social dimensions, such as peer cohesion and involvement, identify the nature and intensity of personal relationships in the work environment, also evaluate the level of involvement and how mutual support is created in the work environment. Dimensions of personal growth, for example professional interests, refer to how personal growth and self-improvement of workers are directed to help the realization of company goals. Third, system maintenance and change dimensions encompass the degree of order in the setting, clarity of expectations, maintenance of control and adjustment to changes. 
Another dimensions presented by Bustillo (2009), that the quality of worklife can be seen from work quality and employment quality. Work quality is related to the material characteristics of the work performed and the environment in which the work is carried out, while employment quality is related to the contractual relationship between employers and employees. According to Bustillo (2009) the elements that influence work quality are work autonomy, physical condition of work, health (both physical and psychosocial), workload, potential risk of accident, social environment at work, and meaningful work. On the other hand, employment quality talks about formal training, job guarantee and stability, wages, working hours, work schedules and work time flexibility, and social benefits (Bustillo, 2009).

\section{Methodology}

In collecting data and answering research questions, the exploratory design with qualitative method is used. Exploratory design is used because we know little or nothing about the phenomenon, and no one has yet explored it (Lawrence, 2014). Moreover, according to Merriam and Tisdell (2016), qualitative method is used when researcher wants to understand how people interpret their experiences, how they construct their worlds, and what meaning they attribute to their experiences. Therefore, the method was chosen because it is comply with the aims of the research, which is to obtain an overview of the employees perception related to the work-life quality, as well as knowing how PT AG implements decent work practices.

To answer the research questions, data are obtained by interviews with nine informants who work at PT AG, where there is a group of field workers and head office workers. The authors used purposive sampling, so the character of the informants was determined at the beginning. The selection of informants is based on the job position, i.e the field workers who have high risk jobs (driver, bus service officer, and patrol officer) who have one year minimum service period. As seen in Figure 1, Informants including Human Resources Department Head, head office worker, and union leader were also selected in order to get a comprehensive perspective and as an effort to avoid bias in research. After the interview is done, the authors did the transcript and coding with three sequences. 

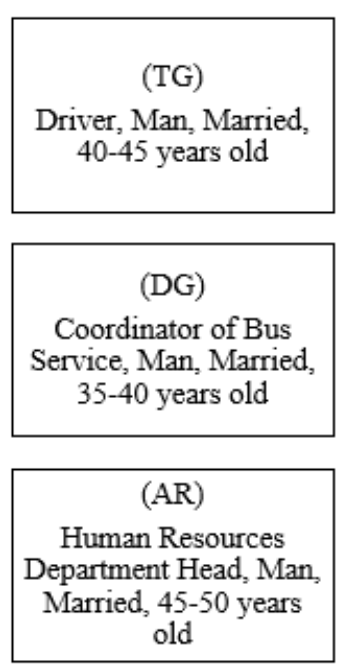

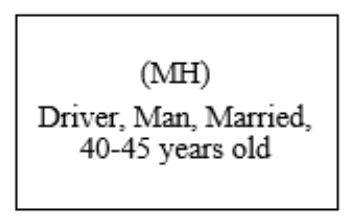

(SG)

Patrol Officers, Man, Married, 30-35 years old

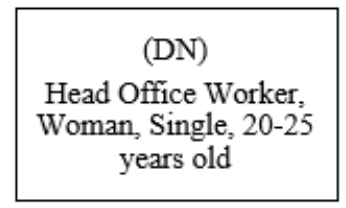

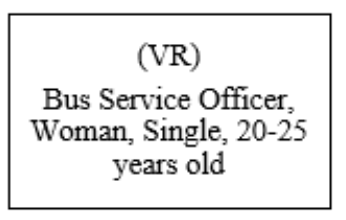

$(\mathrm{AD})$

Patrol Officers, Man, Single, 20-25 years old

\begin{tabular}{|c|}
\hline (BM) \\
Head Office Analyst \\
(Union Labor Head), \\
Man, Married, 40-45 \\
years old
\end{tabular}

Fig. 1. Informants profile.

The internal validity of this research was shore up by triangulation. Though qualitative researchers can never capture an objective "truth" or "reality," triangulation is a strategy that can use to increase the "credibility" of the findings (Merriam \& Tisdell, 2016). According to Denzin (1978), there are four types triangulation: the use of multiple methods, multiple sources of data, multiple investigators, and multiple theories to confirm emerging findings (Merriam \& Tisdell, 2016). This research uses multiple sources of data that gathered from interview, observation, and company regulations as a written document. To get data from multiple points of view, authors did interviews with driver, bus service officer, and patrol officers who have high risk jobs, and also Human Resources Department Head, head office staff, and union labor's head. Thus, it improves accuracy in qualitative method.

\section{Findings}

As a Regionally-Owned Enterprise, PT AG received an injection of subsidy funds to support the company's operational activities in accordance with Governor Regulation No.62 / 2016. The funds is allocated to provide employment opportunities in accordance with the needs and business plans of the company. In other indicators, PT AG endeavors to provide an adequate earnings to its employees by complying the Governor Regulation on Provincial Minimum Wages. However, issue that needs to be concerned is related to the 
pay scale that has not been implemented, so that it causes social jealousy among workers related to the equal income. This issue especially felt by head office workers, while the field workers are not relevant to the problem.

On the other hand, PT AG experienced challenges in terms of meeting the decent working hour indicator. This was especially felt by bus service officers. Even though working hours are mentioned in company regulations, in practice they often work in longer hours than they should and do not get overtime pay. Different condition experienced by drivers who receive Operational Performance Allowances. On the other hand, issue of working hours was not complained by drivers, patrol officers, and head office workers.

The issue of work-life balance which is the core of combining work, family and personal life indicator is also mentioned by field workers who have to work in shifts, especially drivers and bus service officers. They are generally required to work with the provisions of five working days and one day off, so they feel that they only have a little time for family or doing activities beside working. However, this issue was not felt by other workers such as patrol officers and head office workers because the stipulated working hours for them were five working days and two days off.

Regarding to stability and security at work indicator, it has been a special case in the history of employment in PT AG. Information was obtained that before year of 2017, PT AG violated the Manpower Act because the worker was contracted for more than three consecutive years. Up to ten years, some workers at that time still remained as contract employees. This was what triggered the demonstration that was initiated by the PT AG Labor Union. In addition, the informant who work at the head office revealed that PT AG was often late in renewing employment contract, so there were employees who work without written contract for several months. However, in today's context, PT AG has complied with labor regulations in accordance with Indonesian Labour Law No.13/2003.

PT AG also eager to promote equal treatment in the workplace, specifically in guaranteeing women's rights. This was manifested by regulations related to maternity leave, childbirth and menstruation leave that are written in company regulations. However, PT AG needs to pay attention related to giving a 'safe' working condition, especially to the female field workers. This was motivated by a case that occurred when bus service officer lied while doing a job interview related to the condition of her pregnancy. She is afraid of losing the opportunity to get the job because the management requires that female bus service officers may not work while pregnant. According to the management, it would endanger her safety if she work in the condition of pregnant. In addition, in terms of wage equality, no discrimination was found between male and female workers. 
Efforts regarding to the fulfillment of safe work environment indicator are also evident through the provision of work safety equipment for field workers, especially patrol officers, as well as training and special certifications for drivers. As proof of PT AG's seriousness in creating a safe work environment, a Health Safety Environment (HSE) Department was formed and PT AG strives to apply minimum service standards in accordance with the Governor's Regulation. A safe work environment also seeks to be realized at the Head Office, such as the provision of fire extinguishers and emergency stairs. However, adequate infrastructures such as CCTV camera, traffic signs, and adequate lighting are not yet fully available in all operational areas of PT AG.

The ninth indicator of decent work that has been fulfilled by PT AG is related to social security. PT AG provides social security to its workers in accordance with the provisions of National Social Security System Law No.40/2004. PT AG provides health insurance, work accident insurance, pension benefits, pension and life insurance, as stated in company regulations. In addition, other allowances are also given to employees at PT AG.

PT AG also endeavors to support the creation of social dialogue and worker representation in accordance with the ILO's mandate regarding to decent work and Indonesian Labour Law No.13/2003 relating to industrial relations. As a forum for communication between management and workers representatives, there are four labor unions formed in PT AG. In addition, Bipartite Institution, employers' organizations, and dispute resolution have also been formed. While for the Tripartite Cooperation Institution and Collective Labor Agreement have not been formed by PT AG.

Phenomena related to the quality of work-life are conveyed by referring to dimensions of work quality and employment quality (Bustillo, 2009). One element included in the work quality, the psychosocial condition, was revealed by the bus service officers in relation to their responsibilities. As front liners, they are required to always be friendly and responsive to customers. On the other hand, sometimes they have to deal with customers who have unfriendly characters. Coupled with work time that sometimes exceeds schedules and erratic traffic conditions, making their psychosocial conditions often disrupted. In addition, related to employment quality especially work time flexibility, was also conveyed by them. Bus service officers revealed that it was often difficult to carry out activities such as worshipping, going to the toilet, or just eating. This usually happens because the bus schedule is disrupted due to traffic conditions. To avoid the buildup of passengers, they often resume bus operational activities without a break. Thus the indicators regarding employment quality need attention from the management of PT AG. Related to the basic social dimension as another indicator of quality of work-life, relations 
between colleagues (peer cohesion) are also conveyed by bus service officers. They said that the cooperation that was established did not always go well, because of the 'seniority' between 'old employees' and 'new employees', as well as the practice of 'bribery' carried out by unscrupulous bus service officers to the coordinator with the aim to simplifying their work.

PT AG's efforts in creating a work-life quality were also expressed by informants who work as drivers. The fulfillment of work quality indicators can be seen from management's efforts to provide Standard Operating Procedures (SOPs) to protect the their safety. In addition, the company also provides a dormitory that can be used for drivers to take rest. Informants who work as drivers also feel that they have meaningful work and important role for the company's business continuity. While in terms of personal growth, the drivers also expressed their satisfaction because of the training provided by management. Drivers who become the informants also said that the amount of wages and social security provided by PT AG was better than other companies in the same sector of business.

Perceptions regarding to the quality of work-life were conveyed by another group of workers: patrol officers. Different from other field workers, they experience challenges related to the physical condition of work. As the person who is responsible for maintaining smooth traffic on the bus lane, they have to face unpredictable weather, air pollution, and the potential for traffic accidents. Meanwhile, from the employment quality perspective, especially related to work time, patrol officers revealed that the work schedule arrangements for them are better than other field workers. That is because the work schedule set for patrol officers is five working days and two days off, so there is an opportunity for them to have work-life balance. Different to the perceptions held by bus service officers, patrol officers admit that solid cooperation is created between coworkers and this creates a positive working environment.

In contrast to the field workers, when talking about quality of work-life, head office workers mention about the basic social dimension. It is illustrated by the jealousy and sentiments of the 'old workers' group towards the 'new workers' related to wages inequality. However, related to the dimension of personal development, informants who work at the head office revealed that companies provide opportunities for self-development through training programs, job rotations, and programs to improve their soft skills. 


\section{Conclusion}

From the results, it was found that not all indicators related to decent work delivered by the ILO (2013) were implemented at PT AG. As a RegionallyOwned Enterprise, problems related to decent working time, combining work, family and personal life, equal opportunity and treatment in employment, and safe work environment are still felt by high risk workers. This was revealed by informants who work as bus service officers, patrol officers, and drivers. However, PT AG strives to create decent working conditions through adequate earnings and productive employment, compliance with regulations related to work that should be abolished, stability and job security, social security, and a mechanism for conducting social dialogue at work.

Similar to the implementation of decent work, pursuing the quality of worklife at PT AG also faces its own challenges. The informants who work as bus service officer reveal the psychosocial conditions experienced in relation to the work that they do on a daily basis. In addition, issues related to employment quality (work time flexibility) and basic social dimensions (peer cohesion) were also addressed by them. A different condition was experiences by drivers who revealed a good work climate, particularly in employment quality and work quality indicators. As a core business person of the company, drivers are given adequate earnings, as well as the opportunity for personal growth through formal training and a chance to get promotion. Different challenges were also felt by patrol officers, related to health condition and the potential for traffic accident as parts of work quality dimension. However, in terms of employment quality, especially related to work schedules, the patrol officer revealed that the condition was better than other field workers. 
Acknowledgments. We express our gratitude to the Magister of Management Program, Faculty of Economics and Business, University of Indonesia for the support provided in the completion of this research. We also say thank you to the informants, PT AG's management, and another parties who supported and contributed in the process of this research. 


\section{References}

[1] Adhikari, D., Hirasawa, K., Takakubo, Y., \& Lal Pandey, D. Decent work and work life quality in Nepal: An Observation. Employee Relations. 2011; 34(1): 61-79.

[2] Anbarasan, V., \& Nikhil, M. Importance of Emotional Intelligence for Enhancing Empoyee's Perception on Quality of Working Life. Synergy. Vol.VIII No.11. 2010.

[3] Badan Pusat Statistik Indonesia. Decent Work Indicators in Indonesia. BPS RI. 2018.

[4] Burchell, B., Sehnbruch, K., Piasna, A., \& Agloni, N. The Quality of Employment and Decent Work: Definitions, Methodologies, and Ongoing Debates. Cambridge Journal of Economics. 2013; 38(2): 459-477.

[5] Bustillo, R. M. Indicators of Job Quality in the European Union. Directorate General for Internal Policies, Policy Department A: Economic and Scientific Policy. 2009.

[6] Cascio, W. F. Managing Human Resources: Productivity, Quality of Work-Life, Profits. New York: McGraw-Hill; 2006.

[7] International Labour Organization (ILO). Reducing the Decent Work Deficit: A Global Challenge. Report of the Director-General, 89 ${ }^{\text {th }}$ Session. 2001.

[8] International Labour Organization (ILO). Decent Work: Concepts, Models and Indicators. The International Institute for Labour Studies. 2002.

[9] International Labour Organization (ILO). Measurement of Decent Work. Discussion Paper of the Tripartite Meeting of Experts on the Measurement of Decent Work. 2008.

[10] International Labour Organization (ILO). Decent Work Indicators: Guidelines for Producers and Users of Statistical and Legal Framework Indicators. ILO Manual Draft. $2^{\text {nd }}$ version. 2013.

[11] International Labour Organization (ILO). Decent Work. https://www.ilo.org/global/topics/decent-work/lang--en/index.htm. February 11, 2020.

[12] Merriam, S. B., \& Tisdell, E. J. Qualitative Research: A Guide to Design and Implementation. $4^{\text {th }}$ edition. San Francisco: Jossey-Bass; 2016.

[13] Tadjoeddin, M. Z. Decent Work. Asian Journal of Social Science. 2014; 42(1-2), 9-44. 